\title{
Effect of NPK uptake at different growth stages of wheat (Triticum aestivum L.) for yield maximization
}

DIWAKAR PASWAN, ANJANAARUN, AJEET KUMAR AND C.S. CHOUDHARY

MEMBERS OF RESEARCH FORUM:

Corresponding author : DIWAKAR PASWAN, Regional

Research Station, Agwanpur,

SAHARSA (BIHAR) INDIA

Email: diwakarpaswanbau@gmail.com

Co-authors :

ANJANA ARUN, AJEET KUMAR AND

C.S. CHOUDHARY, Regional Research

Station, Agwanpur, SAHARSA (BIHAR)

INDIA

Received : 04.10.2014; Revised : 26.10.2014; Accepted : 13.11 .2014

\section{Summary}

Maximum $\mathrm{N}$ uptake in wheat crop was obtained with successive increase in level of fertilizer, plant population and organic manure application. The maximum $\mathrm{N}$-uptake of $137.64 \mathrm{~kg} / \mathrm{ha}$ was recorded at harvest with the application of highest does of nitrogen i.e., $180 \mathrm{~kg} / \mathrm{ha}$. Application of higher level of fertilizer and organic manure and higher plant population increase the $\mathrm{P}$ uptake. The maximum phosphorus uptake of $17.19 \mathrm{~kg} / \mathrm{ha}$ were recorded at harvest with the application of $75 \mathrm{~kg}$ phosphorus/ha. The same way $\mathrm{K}$ uptake was also observed to increase with increase in level of fertilizer, plant population and organic manure application.

Key words : NPK uptake, Growth stages, Wheat, Yield

How to cite this article : Paswan, Diwakar, Arun, Anjana, Kumar, Ajeet and Choudhary, C.S. (2014). Effect of NPK uptake at different growth stages of wheat (Triticum aestivum L.) for yield maximization. Asian J. Soil Sci., 9(2): 265270. 